Reviu Akuntansi dan Bisnis Indonesia, Vol. 1 No. 2, Hlm: 121-130, Desember 2017

Website: http://journal.umy.ac.id/index.php/rab

\title{
Analisis Faktor-Faktor Yang Mempengaruhi Terjadinya Flypaper Effect Terhadap Belanja Daerah (Studi Empiris Pada Pemerintahan Kabupaten \& Kota di DIY 2010-2016)
}

\author{
Clara Kartika Buana Citra; Bambang Jatmiko \\ Program Studi Akuntansi Univeritas Muhammadiyah Yogyakarta.
}

IN F O A R TIKEL

Kata Kunci:

Flypaper effects, Local

Revenue, General Allocation

Funds, Revenue Sharing,

Local Expenditure

Jenis Artikel:

Penelitian Empiris

Correspondence:

bambang_jatmiko65@yahoo.com

\author{
A B S T R A K
}

\begin{abstract}
Tujuan dari penelitian ini adalah untuk mengetahui faktor-faktor efek flypaper di Daerah Istimewa Yogyakarta, penelitian ini menggunakan data sekunder dari kombinasi 5 kabupaten dan kota selama periode 2010-2016, menggunakan variabel pendapatan lokal, variabel dana alokasi umum, variabel pembagian pendapatan, variabel pengeluaran lokal. Metode yang digunakan dalam penelitian ini adalah analisis regresi berganda dengan perangkat lunak spss. Hasil dari penelitian ini adalah, pertama menunjukkan bahwa pendapatan daerah memiliki hubungan positif dengan pengeluaran lokal, dana alokasi umum signifikan dan memiliki hubungan positif dengan pengeluaran lokal, tetapi bagi hasil memiliki hubungan negatif dan tidak signifikan terhadap pengeluaran lokal, dan kemudian ini Penelitian menunjukkan bahwa ada efek flypaper di DIY, membuktikan bahwa koefisien pendapatan lokal lebih rendah dari koefisien dana alokasi umum untuk pengeluaran lokal.
\end{abstract}

(C) 2019 RAB. Published by Universitas Muhammadiyah Yogyakarta

\section{PENDAHULUAN}

Penerapan demokrasi di Indonesia telah menunjukkan progres yang signifikan hal ini ditandai dengan mulai diberlakukannya otonomi daerah berupa desentralisasi fiskal, sesuai dengan yang tertuang pada UU No 32 Tahun 2004 mengenai pelimpahan wewenang kepada Pemerintah Daerah serta UU No 33 Tahun 2004 mengenai perimbangan keuangan pada Pemerintah Pusat dan Pemerintah Daerah, diberlakukannya UU ini memiliki dampak positif dalam dinamika aspirasi masyarakat didaerah sehingga kebijakan daerah berubah kearah yang lebih demokratis dimana tidak lagi bersifat Uniform dan Given yaitu selalu setara dan sama dalam jumlah penerimaan dari Pemerintah Pusat, namun Pemda harus berperan aktif dalam merumuskan kebijakan daerah yang sesuai dengan karakteristik daerah tersebut meliputi aspirasi, potensi dan sosiokultural masyarakat setempat serta kendala yang dihadapi daerah tersebut, hal ini sesuai dalam Al-Quran pada surat: An-Nisa' (4): 58 Terjemahannya:'Sesungguhnya Allah menyuruh kamu menyampaikan amanat kepada yang berhak menerimanya, dan menyuruh kamu apabila menetapkan hukum diantara manusia supaya kamu menetapkan dengan adil. Sesungguhnya Allah memberi pengajaran sebaikbaiknya kepadamu. Sesungguhnya Allah adalah Maha Mendengar lagi Maha Melihat.”

Desentralisasi fiskal yang mulai diberlakukan sebagai wujud pelaksanaan otonomi daerah ternyata membuat Pemerintahan Daerah bergantung kepada Pemerintahan Pusat, hal ini karena transfer dari pusat kepada daerah setempat dengan maksud menyamaratakan kemampuan keuangan malah lebih banyak atau tinggi dibandingkan pendapatan asli daerahnya inilah yang 
disebut flypaper effect. Flypaper effect merupakan fenomena yang merujuk pada suatu kondisi ketika Pemerintah Daerah menggunakan pembiayaan untuk keperluan belanja daerah lebih tinggi bersumber dari dana transfer, transfer yang dimaksud adalah transfer tak bersyarat (dana alokasi umum, dana alokasi khusus, dana bagi hasil) ketimbang pendapatan asli daerah nya tersebut, hal ini lah yang mengakibatkan pemborosan dalam belanja daerah (Oktavia, 2014). Di Indonesia sendiri fenomena flypaper effect secara umum diartikan sebagai suatu kondisi dimana pembiayaan belanja daerah lebih tinggi menggunakan atau memanfaatkan transfer yang berasal dari dana alokasi umum (DAU) dibandingkan pendapatan asli daerah (PAD).

Flypaper effect terjadi karena 2 syarat yaitu ketika dalam hasil pengujian yang diperoleh menunjukkan (1) besarnya nilai koefisien DAU yang lebih tinggi jika dibandingkan dengan nilai koefisien PAD dan koefisien keduanya signifikan, (2) nilai koefiesien PAD tidak signifikan (Maimunah, 2006). Asumsi penentuan terjadinya flypaper effect dengan membandingkan antara pengaruh PAD serta DAU padaBelanja Daerah.

Selanjutnya penelitian dari Kusumadewi dan Rahman (2007) menyatakan bahwa flypaper effect tidak hanya terjadi pada daerah dengan tingkat PAD yang rendah saja melainkan juga terjadi pada daerah yang memiliki tingkat PAD yang tinggi salah satunya daerah Istimewa Yogyakarta. Yogyakarta sebagai kota pariwisata yang setiap tahunnya selalu dikunjungi oleh turis domestik atau pun mancanegara, seharusnya mampu membiayai belanja daerahnya melalui pendapatan asli daerah. Namun pada kenyataannya flypaper effect sendiri banyak terjadi didaerah Kabupaten/Kota di Daerah Istimewa Yogyakarta, padahal seharusnya daerah ini mampu mengatasi ketergantungannya pada Pemerintah karena memiliki potensi pariwisata yang besar, selain itu DIY merupakan kota pelajar yang setiap tahunnya kedatangan mahasiswa dari berbagai daerah yang justru mempercepat perputaran uang, untuk lebih jelasnya perhatikan table dibawah ini.

Tabel 1.1 Perbandingan PAD terhadap DAU Pemerintah Kota/Kabupaten di DIY Tahun 2016 (Dalam Ribu Rupiah)

\begin{tabular}{lrcc}
\hline Kabupaten/Kota & PAD & DAU & \%PAD terhadap DAU \\
\hline Kulonprogo & 172434611 & 718490508 & $24 \%$ \\
Bantul & 349492790 & 999814365 & $35 \%$ \\
Gunung Kidul & 172352154 & 954997369 & $18 \%$ \\
Sleman & 614410594 & 1014310630 & $60,6 \%$ \\
Yogyakarta & 503488602 & 670278830 & $70 \%$ \\
\hline
\end{tabular}

Sumber : BPS DIY

Tabel diatas merupakan data APBD DIY tahun 2016, dapat dilihat bahwa tingkat kebergantungan Kabupaten Gunung Kidul dan Kulon Progo masih sangat rendah jika dibandingkan daerah lain, walaupun semua Kabupaten atau Kota di Provinsi DIY masih terjadi flypaper effect terbukti DAU lebih tinggi daripada PAD nya namun yang terparah terjadi pada 2 Kabupaten tersebut, data diatas menunjukan bahwa dalam kurun waktu 13 tahun sejak diberlakukannya otonomi daerah Pemerintah Provinsi belum bias melepaskan ketergantungannya terhadap pusat, bahkan di Kota besar sekalipun dengan potensi sumber daya yang besar, hal ini menimbulkan pertanyaan apa penyebab flypaper effect sehingga Pemerintah Provinsi belum dapat melakukan perbaikan yang berarti dalam hal pembiayaannya.

\section{TINJAUAN LITERATUR DAN PERUMUSAN HIPOTESIS}

\section{Teori Pelayanan (Stewardship Theory)}

Stewardship Theory merupakan suatu teori yang menjelaskan situasi dimana para manajer tidak termotivasi terhadap tujuan individu namun lebih termotivasi pada tujuan hasil utama organisasi demi kepentingan bersama, teori ini sebenarnya memiliki dasar psikologi dan sosiologi yang telah dirancang sedemikian rupa dimana steward diperankan oleh para eksekutif yang 
termotivasi agar bertindak sesuai kemauan principal, akan tetapi karena perilaku steward bertujuan untuk mencapai tujuan organisasinya sehingga steward tidak akan meninggalkan organisasinya.

Implikasi teori stewardship dalam penelitian ini yaitu dapat menjelaskan eksistensi Pemerintah Daerah sebagai suatu lembaga yang dapat dipercaya dalam menampung aspirasi masyarakat, dapat memberikan pelayanan yang baik bagi publik, mampu membuat pertanggung jawaban keuangan yang diamanahkan kepadanya, sehingga tujuan ekonomi terpenuhi serta kesejahteraan masyarakat dapat tercapai secara maksimal.

\section{Teori Keagenan(Agency Theory)}

Teori Agensi menguraikan hubungan antara pihak principal (stakeholder) dan agen (steward), dimana principal merupakan pihak yang memberikan mandat kepada agen. Principal memberi kewenangan tanggung jawab pengambil keputusan kepada agen dimana hak dan kewajiban kedua belah pihak diuraikan dalam suatu perjanjian kerja yang telah disepakati dan saling menguntungkan. Principal sebagai pemilik mengontrak agen sebagai eksekutif untuk memanajemen perusahaannya sehingga eksekutif secara moral bertanggung jawab memaksimalkan kepentingan principal (pemegang saham), eksekutif menerima status agen dikarenakan anggapan bahwa ada peluang untuk memaksimalkan kepentingannya (Jensen danMeckling dalam Arfianti, 2011).

Proses penyusunan serta pembentukan anggaran (APBD) melibatkan tim penyusunan yaitu satuan kerja, tim anggaran, dan legislatif seperti DPR, di dalamnya membahas usulan rancangan APBD diantara eksekutif serta legislatif sehingga terjadi suatu kesepakatan yang nantinya akan dicapai dengan cara bargaining, sebelum APBD tersebut sah menjadi Peraturan Daerah, dan disinilah dapat dilihat terjadi hubungan teori keagenan diantara eksekutif maupun legislatif, dengan eksekutif memiliki peran selayaknya agen dan principal diperankan oleh legislatif.

Pendapatan Asli Daerah, berdasarkan Undang - Undang Nomor 33 Tahun 2004, Pendapatan Asli Daerah merupakan pendapatan daerah yang dipungut sesuai dengan yang tertuang dalam peraturan daerah pada peraturan perundang-undangan. PAD diukur dari Pajak Daerah, Retribusi daerah, Lain-lain PAD yang sah serta Hasil pengelolaan kekayaan daerah yang dipisahkan.

Dana Alokasi Umum, berdasarkan Undang - Undang No. 33 Tahun 2004, Dana Alokasi Umum (DAU) merupakan dana yang berasal dari pendapatan APBN yang khusus dialokasikan untuk tujuan kesetaraan kemampuan keuangan antar daerah sehingga Pemda mampu mendanai kebutuhan daerah dalam rangka pelaksanaan desentralisasi. Secara definisi DAU diartikan sebagai salah satu komponen dari dana perimbangan pada APBN, yang pengalokasiannya didasarkan atas konsep kesenjangan fiskal atau celah fiskal (Fiscal Gap), yaitu selisih antara Kebutuhan Fiskal dengan Kapasitas Fiskal. Adapun contoh dari kebutuhan daerah ini adalah luas wilayah/daerah, keadaan geografis, kesehatan serta tingkat kesejahteraan masyarakat, jumlah penduduk dan tingkat pendapatan masyarakat didaerah tersebut, selain itu kapasitas fiskal dapat dilihat dari Pendapatan Asli Daerah, Dana Bagi Hasil Pajak dan Sumber Daya Alam, sedangkan distribusi Dana Alokasi Umum untuk daerah yang berpotensi fiskalnya tinggi tetapi tingkat kebutuhan fiskal rendah akan mendapat distribusi DAU yang kecil, namun apabila daerah berkapasitas fiskalnya rendah namun memiliki kebutuhan fiskal yang tinggi akan mendapat distribusi DAU yang besar.

Dana Bagi Hasil merupakan dana yang berasal dari pendapatan APBN yang diperuntukkan kepada daerah berdasarkan angka presentase yang telah ditentukan dengan tujuan untuk membiayai kebutuhan daerah dalam rangka keberhasilan pelaksanaan program desentralisasi, dana bagi hasil terdiri atas DBH Pajak dan DBH Sumber daya alam bersumber dari UU No. 33 tahun 2004. Dana Bagi Hasil (DBH) yang berasal dari pajak terdiri dari : Pajak Bumi dan Bangunan (PBB), Bea Perolehan Hak atas Tanah dan Bangunan (BPHTB), Pajak Penghasilan (PPh) Pasal 25 dan Pasal 29 Wajib Pajak Orang Pribadi Dalam Negeri dan PPh Pasal 21. Sedangkan Dana Bagi Hasil (DBH) yang berasal dari sumber daya alam adalah kehutanan, pertambangan umum, perikanan, pertambangan minyak bumi, pertambangan gas bumi, pertambangan panas bumi" (UU No. 33 Tahun 2004). 
Belanja Daerah, menurut (Kusumadewi dan Rahman, 2007) belanja daerah merupakan semua bentuk pengeluaran biaya kas daerah dalam satu periode anggaran yang menjadi beban daerah. sedangkan menurut UU No. 32 Tahun 2004, definisi belanja daerah adalah belanja yang dilakukan dengan tujuan untuk membiayai beban pengeluaran Pemerintah Daerah, sebaliknya urusanPemerintah Pusat dibiayai oleh beban APBN.

Flypaper effect merupakan konsekuensi akibat adanya kontrak politik dalam Pemerintah Daerah. Gorodnichenko dalam Kuncoro (2007), menyatakan bahwa suatu kondisi dapat dikatakan terjadi Flypaper effect apabila memenuhi dua keadaan, pertama adalah meningkatnya pajak daerah dan belanja daerah terlalu boros, kedua karena tingginya elastisitas dari pengeluaran terhadap transfer jika dibandingkan dengan elastisitas pengeluaran terhadap penerimaan pajak daerah. Flypaper effect terjadi karena 2 syarat yaitu ketika dalam hasil pengujian yang diperoleh menunjukkan (1) besarnya nilai koefisien DAU yang lebih tinggi jika dibandingkan dengan nilai koefisien PAD dan koefisien keduanya signifikan, (2) nilai koefiesien PAD tidak signifikan (Maimunah, 2006). Asumsi penentuan terjadinya flypaper effect dengan membandingkan antara pengaruh PAD serta DAU pada belanja daerah. Melo (2005) dan Venter (2007) mengemukakan terjadinya flypaper effect dikarenakan hasil pengamatan nilai koefisien DAU pada belanja daerah lebih tinggi jika dibandingkan dengan nilai koefisien PAD pada belanja daerah, selain itu dari hasil analisis membuktikan bahwa nilai koefisien PAD pada belanja daerah tidak signifikan, sehingga dapat dibuat suatu kesimpulan terjadi flypaper effect.

\section{Pengaruh PAD terhadap Belanja Daerah}

Tingkat kemandirian dalam suatu daerah dapat digambarkan melalui tingginya tingkat PAD yang didapat oleh Pemerintah Daerah, sehingga semakin tinggi tingkat PAD yang diterima maka besar kemungkinan daerah tersebut mampu memenuhi kebutuhan belanjanya sendiri dan tidak tergantung pada Pemerintah Pusat, hal ini menunjukkan Pemerintah Daerah tersebut bisa dikatakan daerah otonom. Pada dasarnya salah satu komponen pembiayaan belanja daerah adalah PAD, sehingga apabila PAD meningkat maka belanja daerah juga meningkat karena kebutuhan belanja daerah yang semakin meningkat.

Penelitian Iskandar (2012) mengungkapkan bahwa hasil koefisien PAD memiliki pengaruh signifikan positif pada Belanja Daerah, peneliti lain yaitu Oktavia (2014) juga menyimpulkan bahwa PAD berpengaruh signifikan positif terhadap belanja daerah, selain itu penelitian dari Rahmawati (2015) menyatakan bahwa PAD memiliki pengaruh positif signifikan terhadap BD, bahkan Pemerintah Daerah yang memiliki tingkat PAD tinggipun, pengeluaran untuk alokasi Belanja Daerahnya juga semakin tinggi.

Perilaku tersebut sesuai dengan teori pelayanan Davis, Schorman dan Donaldson dalam Mutaqqin, (2014) teori ini menunjukkan situasi dimana para manajer tidak dimotivasi oleh tujuantujuan individu tetapi lebih termotivasi pada tujuan utama mereka yang telah disepakati dalam organisasi. Namun tidak selamanya pemerintah menaikkan pajak hanya sekedar untuk meningkatkan pendapatan daerahnya, ada pula karena perbaikan fasilitas pelayanan dan naiknya kebutuhan hidup setiap tahunnya.

\section{$\boldsymbol{H}_{I} \quad$ :PAD berpengaruh positif terhadap Belanja Daerah}

\section{Pengaruh DAU terhadap Belanja Daerah}

DAU merupakan salah satu sumber utama pembiayaan belanja daerah selain PAD, dan dana perimbangan lainnya. Semakin besar tingkat DAU yang didapat oleh Pemerintah Daerah menggambarkan kemandirian daerah tersebut, sehingga apabila daerah tersebut semakin banyak menerima DAU maka dapat disimpulkan bahwa daerah tersebut masih ketergantungan terhadap Pemerintah Pusat, dapat digambarkan bahwa daerah tersebut belum mandiri dan belum mampu 
menjadi daerah otonom menurut UU No. 32 Tahun 2004, hal inilah yang menyebabkan flypaper effect.

Penelitian Pramuka (2010) membuktikan bahwa Dana Alokasi Umum ternyata berpengaruh positif signifikan pada Belanja Daerah. Penelitian lain dilakukan Aprilia dan Redo (2013) juga membuktikan bahwa terdapat pengaruh yang positif dari DAU terhadap BD, selanjutnya penelitian dari Saputri dan Dul Muid (2014) menyatakan bahwa DAU berpengaruh positif signifikan terhadap BD dengan sampel dari Pemerintah Daerah Kabupaten/Kota pada Provinsi di Jawa Tengah, kemudian penelitian Adiputra (2014) dengan studi pada Kabupeten Karang Asem menyatakan hasil yang sama bahwa DAU berpengaruh signifikan terhadap BD.

Teori keagenan oleh Jensen dan Meckling dalam Arfianti (2011) menjelaskan bahwa pihak yang memiliki andil pada proses penyusunan suatu anggaran cenderung bersifat untuk memanfaatkan dengan maksimal utilitasnya dengan cara mengalokasikan sumber daya pada anggaran, eksekutif berperan sebagai pihak yang mengusulkan anggaran tersebut dan sekaligus sebagai pelaksana anggaran memiliki tujuan agar jumlah anggaran digunakan semaksimal mungkin, sedangkan legislatif merupakan wakil rakyat mengambil peran dengan menggunakan anggaran sebagai alat pengendalian serta pengawasan,sehingga legislatif mampu merubah jumlah anggaran serta merubah distribusi belanja (Rustiyaningsih, 2012).

\section{$\boldsymbol{H}_{3}:$ PDAU berpengaruh positif terhadap Belanja Daerah}

\section{Pengaruh DBH terhadap Belanja Daerah}

Teori keagenan mendasari hipotesis ini karena DBH merupakan bagian dari dana transfer yang tujuannya untuk pemerataan kemampuan keuangan hanya saja besar kecilnya tergantung kondisi pajak dan sumber daya alam masing - masing daerah, namun memang tidak sebesar DAU akan tetapi DBH juga memiliki andil dalam pembiayaan belanja daerah. Penelitian Sasana (2010) menyatakan bahwa koefisien DBH memiliki pengaruh positif terhadap belanja daerah sehingga disimpulkan bahwa setiap peningkatan DBH sebesar 1 juta rupiah berpengaruh dengan bertambahnya belanja daerah sebesar 1,19 juta rupiah, selain itu penelitian Iskandar (2012) menyatakan bahwa unconditional grant atau transfer tak bersyarat (DAU,DBH) memiliki pengaruh signifikan positif terhadap belanja daerah.

Hasil studi ini juga mendukung temuan empiris Deller et al (2007), Darwanto dan Yulia(2007), Maimunah (2006), dan yang menyatakan bahwa Unconditional Grants (DAU,DBH) merupakan bentuk dana transfer yang penting selain DAK, namun hasil ini tidak dapat digeneralisasikan keseluruh daerah, kalau penelitian sebelumnya lebih banyak meneliti Unconditional Grant dikarenakan di sebagian daerah dipulau Jawa DAU dialokasikan lebih besar dibandingkan DBH bahkan DAK, namun penelitian Riswandi (2014) menyatakan bahwa terjadi flypaper effect di Aceh dikarenakan koefisien PAD terhadap BD, lebih rendah daripada koefisien DBH terhadap BD, hal ini membuktikan bahwa tidak semua daerah memiliki DBH yang tidak lebih besar dibandingkan DAU, semua berdasarkan potensi daerah masing - masing.

\section{$\boldsymbol{H}_{3}$$$
\text { : DBH berpengaruh positif terhadap Belanja Daerah }
$$

\section{METODE PENELITIAN}

Obyek pada penelitian ini adalah Kabupaten dan Kota di seluruh Pemerintah Provinsi Daerah Istimewa Yogyakarta meliputi Kabupaten Kulonprogo, Kabupaten Bantul, Kabupaten Gunung Kidul, Kabupeten Sleman dan Kota Yogyakarta, menggunakan data variabel belanja daerah yang digunakan sebagai variabel dependen dan variabel pendapatan asli daerah, dana alokasi umum, serta dana bagi hasil, adalah digunakan sebagai variabel independen, Kabupaten/Kota dari Tahun 2010 hingga Tahun 2016. Populasi pada penelitian ini meliputi adalah seluruh Pemerintah 
Kabupaten/Kota di Provinsi Daerah Istimewa Yogyakarta (DIY) meliputi Kulon Progo, Bantul, Sleman, Gunung Kidul, dan Kota Yogyakarta. Sedangkan Sub Populasi dalam penelitian ini adalah seluruh laporan realisasi penerimaan dan pengeluaran Pemerintah Kabupaten dan Kota di seluruh DIY. Teknik Pengumpulan Data, Data yang dihimpun dalam penelitian ini menggunakan metode library research atau kepustakaan.

\section{Teknik Analisis Data}

a. Uji Asumsi Klasikal

1) Uji Normalitas

Uji normalitas yang digunakan adalah kolmogorov sminov, yakni jika nilai hasil uji sig lebih besar dari 5\% maka dapat disimpulkan bahwa data berdistribusi normal.

2) Uji Multikolinearitas

Uji Multikolinearitas dilakukan dengan melihat nilai toleranceatau variance inflation faktor (VIF). Jika nilai tolerance $>0,10$ dan VIF $<10$, sehingga data dapat dikatakan bebas dari multikolinieritas.

3) Uji Heterokedastisitas

Uji Heteroskedastisitas dapat diketahui dengan menggunakan uji Glesjer. Apabila probabilitas signifikansi dari masing-masing variabel independen > 0,05, disimpulkan bahwa heteroskedastisitas tidak terjadi pada model regresi.

4) Uji Autokorelasi

Untuk dapat menentukan autokorelasi yaitu dengan menggunakan uji Durbin-Watson.

b. Uji Regresi

Pada penelitian ini semua hipotesis diuji dengan menggunakan model regresi linear berganda. Jenis data yang dipakai dalam penelitian ini merupakan data kuantitatif, dengan jenis time series dalam bentuk tahunan.

Uji Statistik yang digunakan meliputi :

1) Pengujian Koefisien Korelasi

2) Pengujian Simultan

3) Pengujian Faktor Residu/ Sisa

4) Pengujian Hipotesis dengan menggunakan uji t

\section{HASIL DAN PEMBAHASAN}

Dari hasil pengolahan SPSS, persamaan regresi yang diperoleh adalah sebagai berikut: $\mathrm{BD}=-3 \mathrm{E}+008+1.708 \mathrm{PAD}+1.915 \mathrm{DAU}+(-1.033) \mathrm{DBH}+\mathrm{e}$

Tabel 2.1

\begin{tabular}{ccccc}
\hline Model & R & R Square & Adjusted R Square & Std. Error of the Estimate \\
\hline 1 & .976 & .952 & .947 & 135362798 \\
\hline
\end{tabular}

Sumber : Data sekunder yang diolah, 2017 
Pada tabel 2.1 tersaji bahwa koefisien determinasi yang ditunjukkan dari nilai Adjusted $R$ Square sebesar 0,947 hal ini berarti bahwa 94,7\% variasi Anggaran Belanja Daerah dapat dijelaskan oleh variasi dari variabel independen yaitu Pendapatan Asli Daerah (PAD), Dana Alokasi Umum (DAU), Dana Bagi Hasil (DBH). Sedangkan sisanya 5,3\% dijelaskan oleh sebab lain diluar model

Tabel: 2.2 Hasil Uji F

\begin{tabular}{|c|c|c|c|c|c|}
\hline Model & $\begin{array}{l}\text { Sum } \\
\text { Squares }\end{array}$ & $\mathrm{df}$ & Mean Square & $\mathrm{F}$ & Sig \\
\hline Regression & 1. $1 \mathrm{E}+019$ & 3 & $3.764 \mathbf{E}+018$ & 205.444 & $.000^{\mathrm{a}}$ \\
\hline
\end{tabular}

Sumber : Data sekunder yang diolah, 2017

Dari uji ANOVA atau F-test pada tabel 2.2, diperoleh F-hitung 205.444 dengan p value sebesar 0,000. Karena nilai p value lebih kecil daripada alpha 0,05 maka model regresi ini bisa dipakai untuk menjelaskan Belanja Daerah. Dengan demikian, Pendapatan Asli Daerah (PAD), Dana Alokasi Umum (DAU), Dana Bagi Hasil (DBH) berpengaruh terhadap Belanja Daerah.

\section{Uji Hipotesis}

Pengujian ini untuk menguji secara parsial apakah variabel independen secara terpisah berpengaruh terhadap variabel dependen.

Tabel 2.3 Hasil Regresi Berganda

\begin{tabular}{llllll}
\hline & \multicolumn{3}{l}{ Unstandardized Coefficients } & \multicolumn{2}{l}{$\begin{array}{l}\text { Standardized } \\
\text { Coefficients }\end{array}$} \\
\cline { 2 - 4 } Mode & $\mathrm{B}$ & Std Error & Beta & t & Sig. \\
\hline (Constanta) & $-3 \mathrm{E}+008$ & $1 \mathrm{E}+008$ & & -2.306 & .028 \\
PAD & 1.708 & .164 & .507 & 10.404 & .000 \\
DAU & 1.915 & .160 & .597 & 11.994 & .000 \\
DBH & -1.033 & 1.066 & -.041 & -.970 & .340 \\
\hline
\end{tabular}

Sumber: Hasil pengolahan data sekunder, 2017

\section{Pendapatan Asli Daerah terhadap Belanja Daerah}

Hipotesis pertama menyatakan Pendapatan Asli Daerah berpengaruh pada Belanja Daerah, berdasarkan hasil uji tes yang dilakukan membuktikan bahwa Pendapatan Asli Daerah (PAD) berpengaruh positif dan signifikan terhadap belanja daerah pada Pemerintah Kabupaten/Kota di Provinsi Daerah Istimewa Yogyakarta (DIY) dengan nilai sig dari Pendapatan Asli Daerah yang lebih kecil dari nilai a $(0,05)$, hal ini disebabkan karena adanya peningkatan PAD yang dikelola oleh daerah membuat masyarakat sadar akan wajib pajak serta seimbang dalam pelayanan publik serta fasilitasnya, hal ini mengindikasikan bahwa kenaikan PAD juga akan mempengaruhi Belanja. Daerah, karena kebutuhan masyarakat serta tuntutan publik yang harus terus diperbaharui, PAD berasal dari Pendapatan Daerah yang diperoleh dari sumber antara lain Pajak Daerah, Retribusi Daerah, Hasil Pengelolaan Kekayaan Daerah yang Dipisahkan, Lain-lain PAD yang sah yang kesemuanya adalah pelayanan publik yang harus selalu diperbaharui serta dipelihara agar masyarakat memperoleh manfaat dari hasil iuran pajak mereka.

\section{Dana Alokasi Umum terhadap Belanja Daerah}

Hipotesis kedua menyatakan bahwa Dana Alokasi Umum (DAU) berpengaruh terhadap pengalokasian anggaran Belanja Daerah. Berdasarkan hasil pengujian yang dilakukan menunjukan juga Dana Alokasi Umum (DAU) berpengaruh positif dan signifikan terhadap pengalokasian anggaran Belanja Daerah pada Pemerintah Kabupaten/Kota di Provinsi Daerah Istimewa Yogyakarta (DIY) yang ditunjukkan dengan nilai sig dari Dana Alokasi Umum yang lebih kecil dari 
nilai a (0,05). Hal ini menandakan bahwa Pemerintah Daerah mengalokasikan DAU pada Belanja Daerah dengan baik, selain itu DAU merupakan bentuk dana perimbangan yang paling tinggi dibandingkan dengan DBH dan DAK, namun besaran DAU mempengaruhi apakah daerah tersebut mampu atau tidak untuk mandiri dalam kaitannya dengan desentralisasi dan otonomi daerah. Berdasarkan hasil yang telah diperoleh didapat kesimpulan bahwa telah terjadi flypaper effect terbukti lebih tingginya koefisien dana alokasi umum dibandingkan koefisien PAD terhadap BD hal ini membuktikan penelitian Maimunah (2006), Melo (2005) dan Venter (2007) bahwa flypaper effect terjadi berdasarkan tingkat kenaikan atau penurunan PAD dan DAU.

\section{DBH terhadap Belanja Daerah}

Hipotesis ketiga menyatakan bahwa Dana Bagi Hasil memiliki pengaruh positif pada alokasi Belanja Daerah. Berdasarkan hasil pengujian yang dilakukan membuktikan bahwa Dana Bagi Hasil tidak berpengaruh signifikan dan negatif terhadap Belanja Daerah pada Pemerintah Kabupaten/Kota di Daerah Istimewa Yogyakarta, yang ditunjukkan dengan nilai sig dari Dana Bagi Hasil lebih besar dan negatif terhadap Belanja Daerah. Hal ini disebabkan oleh DBH yang merupakan salah satu Dana Perimbangan namun pengalokasiannya berbeda dengan DAU dan DAK, pengalokasian DBH tergantung dari Pajak dan Sumber Daya Alam masing-masing, hal ini berarti apabila perolehan pajaknya antara lain PBB, BPHTB, Pajak Penghasilan WP,OP serta Sumber Daya Alamnya yang sedikit maka secara otomatis dana bagi hasilnyapun sedikit. Di DIY sendiri memang berbeda dengan daerah lain yang memiliki prosentase DBH bahkan lebih kecil daripada DAK, hal ini dikarenakan daerah ini, potensinya adalah pariwisata yang sebagiannya adalah pantai, untuk pertambangan hanya diperoleh dari hasil pertambangan pasir gunung merapi, dan mengingat sebagian wilayah seperti hutan sudah banyak tergusur seiring banyaknya populasi mahasiswa yang meningkat sehingga makin memperkecil prosentase DBH, selain itu DIY merupakan wilayah provinsi yang cukup kecil jika dibandingkan dengan Provinsi lain.

\section{KESIMPULAN}

Penelitian ini untuk menguji secara empiris mengenai analisis faktor-faktor terjadinya flypaper effect terhadap Belanja Daerah pada Pemerintah Kabupaten/Kota di Provinsi Daerah Istimewa Yogyakarta. Berdasarkan hasil penelitian yang telah dilakukan dengan mengambil sampel sebanyak 5 Pemerintah Daerah Kabupaten/Kota yang berada di Provinsi DIY selama tahun 20102016, dapat ditarik kesimpulan pendapatan Asli Daerah berpengaruh signifikan positif terhadap belanja daerah pada Pemerintah Kabupaten/Kota di Daerah Istimewa Yogyakarta. Dana Alokasi Umum berpengaruh positif dan signifikan terhadap belanja daerah pada Pemerintah Kabupaten/Kota Daerah Istimewa Yogyakarta. Dilihat dari koefisien antara PAD dengan BD serta DAU dengan BD dapat dilihat bahwa telah terjadi flypaper effect, hal ini terbukti dari tingginya koefisien antara DAU terhadap BD. Dana Bagi Hasil berpengaruh negatif dan signifikan terhadap belanja daerah hal ini dikarenakan DBH di Provinsi DIY.

Berdasarkan kesimpulan, adapun saran-saran yang dapat penulis ajukan dan berikan sehubungan dengan hasil penelitian ini untuk memperbaiki penelitian selanjutnya diharapkan penelitian-penelitian mendatang mampu memperluas jangkauan populasi dan sampel penelitian seperti Kabupaten/Kota se-Jawa ataupun se-Indonesia dengan periode pengamatan yang lebih panjang. Penelitian selanjutnya juga diharapkan dapat menambah variabel-variabel penelitian lain yang berkaitan dengan penelitian ini sehingga hasil penelitian mampu dipaparkan secara kompleks sesuai dengan teori yang mendukung. Diharapkan peneliti selanjutnya mampu menjelaskan variabel internal penyebab terjadi flypaper effect, seperti wawancara langsung pihak yang terlibat pada penyusunan APBD, tepatnya pada saat memutuskan anggaran DAU. 


\section{DAFTAR PUSTAKA}

Adiputra, I. M. P. (2014). Flypaper effectpada Dana Alokasi Umum dan Pendapatan Asli Daerah terhadap Belanja Daerah di Kabupaten Karang Asem. Jurnal Ilmiah Akuntansi. 3 (2).

AL-QURAN: Surat An-Nisa (4).58

Aprilia, N. \& Saputra, R. A. (2013). Pengaruh Flypaper Effect, Dana Alokasi Umum, dan Pendapatan Asli Daerah Terhadap Belanja Daerah Kabupaten/Kotadi Indonesia'. Jurnal Akuntansi, 3(2). 107-132.

Arfianti, D. (2011). 'Analisis faktor-faktor yang mempengaruhi nilai informasi pelaporan keuangan pemerintah daerah (studi pada satuan kerja perangkat daerah di kabupaten Batang)'. Skripsi Universitas Diponegoro Semarang.

Darwanto \& Yustikasari, Y. (2007). Pengaruh Pertumbuhan Ekonomi Pendapatan Asli Daerah dan Dana Alokasi Umum terhadap Pengalokasian Anggaran Belanja Modal. Simposium Nasional AkuntansiX. Makasar.

Deller, S., Craig S. M., \& Lledo, V. (2007). Wisconsin Local Government, State Share Revenue and the Illusive FlypaperEffect. J.of Public Budgeting, Accountingand Financial Management, 19 (2), 200-220.

Iskandar, I. (2012). Flypaper Effect pada Unconditional Grants. Jurnal Ekonomi Pembangunan. Universitas Padjajaran. 13(1), 113-131.

Kuncoro, H. (2007). Fenomena Flypaper Effect pada Kinerja Keuangan Pemerintah Daerah Kota dan Kabupaten di Indonesia. Simposium Nasional Akuntansi X, UNHAS Makasar, 26-28 Juli 2007.

Kusumadewi, D. A. \& Rahman, A. (2007). Flypaper Effect pada Dana Alokasi Umum (DAU) dan Pendapatan Asli Daerah (PAD) terhadap Belanja Daerah Pada Kabupaten/Kota Di Indonesia'. JAAI, 11 (1), 67-80.

Maimunah, M. (2006). Flypaper Effect pada Dana Alokasi Umum (DAU) dan Pendapatan Asli Daerah (PAD) terhadap Belanja Daerah pada Kabupaten/Kota di Pulau Sumatra. Simposium Nasional Akuntansi IX, Padang.

Melo, L. (2005). The Flypaper EffectUnder Different Institutional Contexts: The Colombian Case (2002). Public Choice 111, 3-4.

Muttaqin, H. (2014). Teori Stewardship (Stewardship Theory), http://library.binus.ac.id/eColls/eThesisdoc/Bab2/201100604mn\%20bab\%202.pdf. Diakses tanggal 15 Mei $2017 \mathrm{pk} 10.40$ WIB.

Oktavia, D. (2014). Flypaper Effect: Fenomena serial waktu dan lintas kabupaten dan kota di Jatim 2003-2013. Jurnal Akuntansi Universtas Jember, 12, 2.

Pramuka, B. A. (2010). Flypaper Effect Pada Pengeluaran Pemerintah Daerah Di Jawa. Jurnal Ekonomi Pembangunan Universitas Jenderal Soedirman. 11 (1), 1-12.

Rahmawati, L. A. (2015). Flypaper Effect, Dana Alokasi Umum dan Pendapatan Asli daerah terhadap Belanja Daerah. Jurnal Ilmu dan Riset Akuntansi STIESIA Surabaya, 4 (9).

Riswandi. (2014). Apakah Flypaper Effect terjadi di Aceh? (Studi mengukur kemandirian keuangan daerah). QEJournal, 3 (4).

Rustiyaningsih, S. (2012). APBD dan Flypaper Effect. Jurnal Krida Rakyat Unika Widya Mandala Madiun.

Saputri, M. A. \& Muid, D. (2014). Flypaper effect pada Dana Alokasi Umum dan Pendapatan Asli Daerah terhadap Belanja Daerah pada Kabupaten/Kota di Jawa

Sasana, H. (2010). Flypaper Effect pada Dana Alokasi Umum, Dana Bagi Hasil, dan Pendapatan Asli Daerah terhadap Belanja Daerah pada Provinsi di Indonesia. Jurnal Eko-Regional, 5 (2).

UU No. 18/1997 tentang Pajak Daerah dan Retribusi Daerah.

UU No. 32/2004 tentang Pemerintahan Daerah (revisi atas UU No. 22/1999).

UU No.33/2004 tentang Perimbangan Keuangan antara Pemerintah Pusat danPemerintah Daerah (revisi atas UU No. 25/1999). 
Citra \& Jatmiko / Reviu Akuntansi dan Bisnis Indonesia, 1(2), 121-130.

UU No.34/2000 tentang Perubahan atas Undang-undang Republik Indonesia No. 18 tahun 1997 tentang Pajak dan Retribusi Daerah.

Venter, D. (2007). Democracy and Multiparty Politics in Africa, Eassrr, Vol. XIX, No.1. 